\title{
UNWEATHERED, GLACIATED BEDROCK ON AN EXPOSED LAKE BED IN WALES
}

\author{
By J. M. GRAY \\ (Department of Geography, Queen Mary College, University of London, Mile End Road, \\ London E1 4NS, England)
}

\begin{abstract}
In Snowdonia, north-west Wales, the construction of a hydro-electric scheme involved the exposure of a lake bed. Despite the fact that it is over 13000 years since the bed was glaciated, erosional features on the slate and grit bedrock have been preserved from weathering below the lake waters. Examples of abrasion, bedrock fracture, plucking, and melt-water erosion are described. The formation of transverse friction cracks is briefly discussed and it is suggested that not all crescentic gouges are associated with rolling blocks as recently proposed. The relationship of small-scale erosional forms to the direction of ice movement is briefly reviewed.
\end{abstract}

RÉSUMÉ. Un bedrock glaciaire non alteré sur un lac mis à sec au Pays de Galles. A Snowdonia, au NordOuest du Pays de Galles, la construction d'un aménagement hydroélectrique a entraîné la mise à jour du fond d'un lac. En dépit du fait qu'il s'est écoulé plus de 13000 ans depuis que ce lit a été englacé, les traces de l'érosion sur l'ardoise et le grès du lit rocheux ont été préservées des atteintes du temps par les eaux du lac. On décrit des exemples d'abrasion, de fractures du lit rocheux, d'arrachement et d'èrosion par l'eau de fusion. On discute brièvement la formation de fissures de friction et l'on suggère que toutes les gorges creusées en forme de croissant ne sont pas associèes avec des blocs roulants comme on l'a récemment proposé. On passe en revue brièvement les relations entre les formes d'érosion à petite èchelle et la direction du mouvement de la glace.

Zusammenfassung. Ein unverwittertes Gletscher-Felsbett auf einem freigelegten Seegrund in Wales. Der Bau einer Wasserkraftanlage in Snowdonia, Nordwest-Wales, erforderte die Freilegung eines Seegrundes. Obwohl 13000 Jahre seit der Eisbedeckung des Grundes vergangen sind, wurden die Erosionserscheinungen auf dem Schiefer- und Sandgriessbett unter dem Seewasser vor der Verwitterung bewahrt. Beispiele von Abrasion, Bruchbildungen, Zerreissungen und Erosion durch Schmelzwasser werden beschrieben. Die Bildung von Rissen durch Reibung wird kurz behandelt; dabei ergibt sich die Vermutung, dass entgegen neueren Annahmen nicht alle Sichelbrüche von Blöcken im bewegten Eis herrühren. Die Beziehung kleinmasstäbiger Erosionsformen zur Richtung der Eisbewegung wird kurz umrissen.

\section{INTRODUCTION}

Glacial geomorphologists living in presently unglaciated areas of the world must normally travel some distance to study freshly deglaciated terrain. Occasionally, however, unweathered glaciated bedrock is revealed in areas that have not been glaciated for many thousands of years. The most common example is where till is stripped off bedrock during construction work, but a less frequent opportunity arises where a lake bed is exposed during construction or operation of a hydro-electric power scheme or other engineering project.

During construction of the Dinorwic hydro-electric pumped storage scheme near Llanberis, Snowdonia, north-west Wales (Fig. 1), the largest such scheme in Europe, the water was pumped from the two lakes that were to form the upper and lower reservoirs for the scheme. Some smallscale glacial features exposed on unweathered bedrock from the floor of the upper reservoir, Marchlyn Mawr, have been described in a previous paper (Gray and Lowe, 1982). This paper describes glacial features from the bed of the lower reservoir (Llyn Peris), and aims to draw the attention of glacial geomorphologists to the opportunities for research at such sites. 


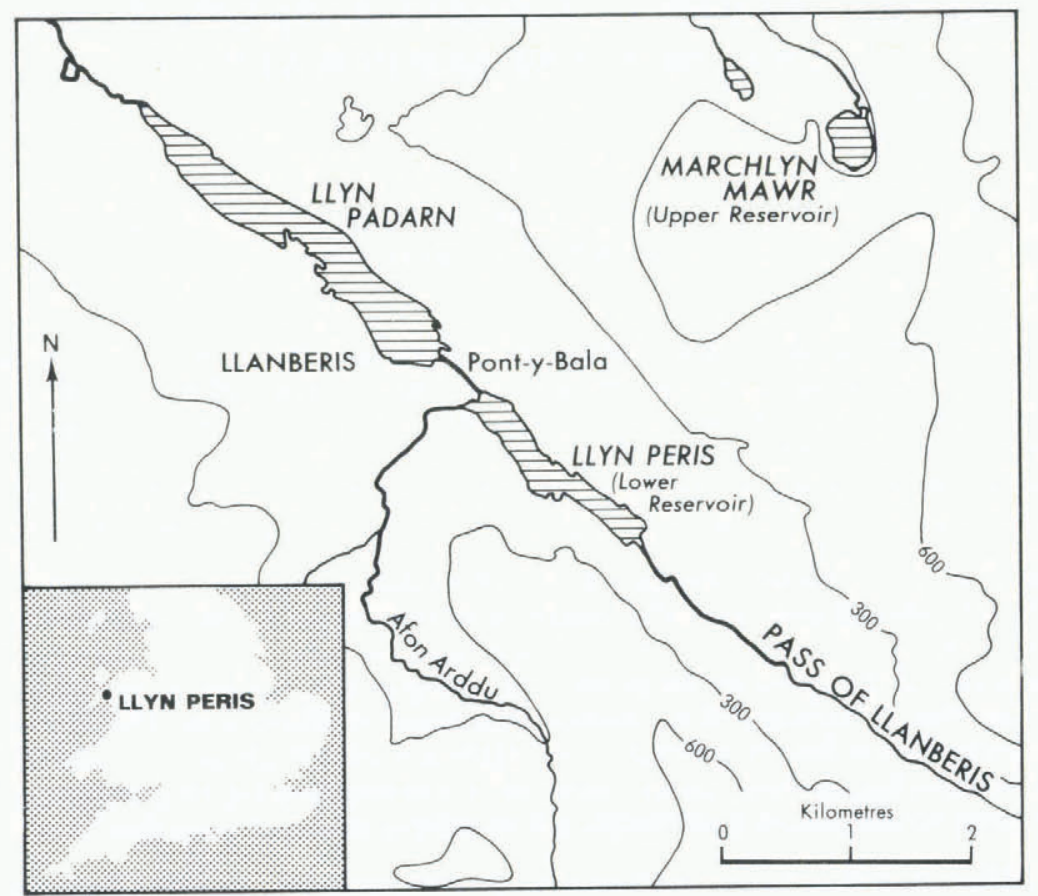

Fig. 1. Location map of the Llyn Peris area, north-west Wales.

\section{STUDY AREA}

Llyn Peris, together with Llyn Padarn to the north-west, occupy an overdeepened basin towards the lower end of the Pass of Llanberis glacial trough (Fig. 1). The two lakes were formerly continuous but have been divided by the growth of a fan at Pont-y-Bala deposited from the south-west by the Afon Arddu. Before construction work began, the lake surfaces lay at about $100 \mathrm{~m}$ O.D. but bore holes sunk at the south-east end of Llyn Peris and on the Pont-y-Bala fan indicate rockhead at $45 \mathrm{~m}$ O.D. at both sites. The bore holes revealed considerable thicknesses of glacial lake rhythmites, sands and gravels, organic lake mud and wood-debris peats overlying bedrock (Tinsley and Derbyshire, 1976). The bedrock in the area is largely Cambrian slate with cleavage and joints mainly trending transverse to the long axis of the lake, although Cambrian grits crop out along the south-west shore of the lake as far north as site 12 (Fig. 2).

Prior to construction, Llyn Peris was about $1.1 \mathrm{~km}$ long and about $300 \mathrm{~m}$ wide at the widest point about half-way along the lake where there is a bay on the south-west shore (Fig. 2). Most of the north-east side has been disturbed by the now disused Dinorwic slate workings and prior to construction much of this shore consisted of slate waste. The presence of this disturbance accounts for the fact that most of the bedrock sites studied in this paper lie along the south-west side of the lake bed (Fig. 2). The deep central strip of the lake is underlain by soft lake sediments which were covered with slate waste during construction so that it was possible to walk about on the former lake floor and examine many of the steep rock faces forming the sides of the trough. From these slopes muds and other sediments were largely removed by mechanical diggers to expose the bedrock and at site A (Fig. 2) a thick area of silty till was removed which 


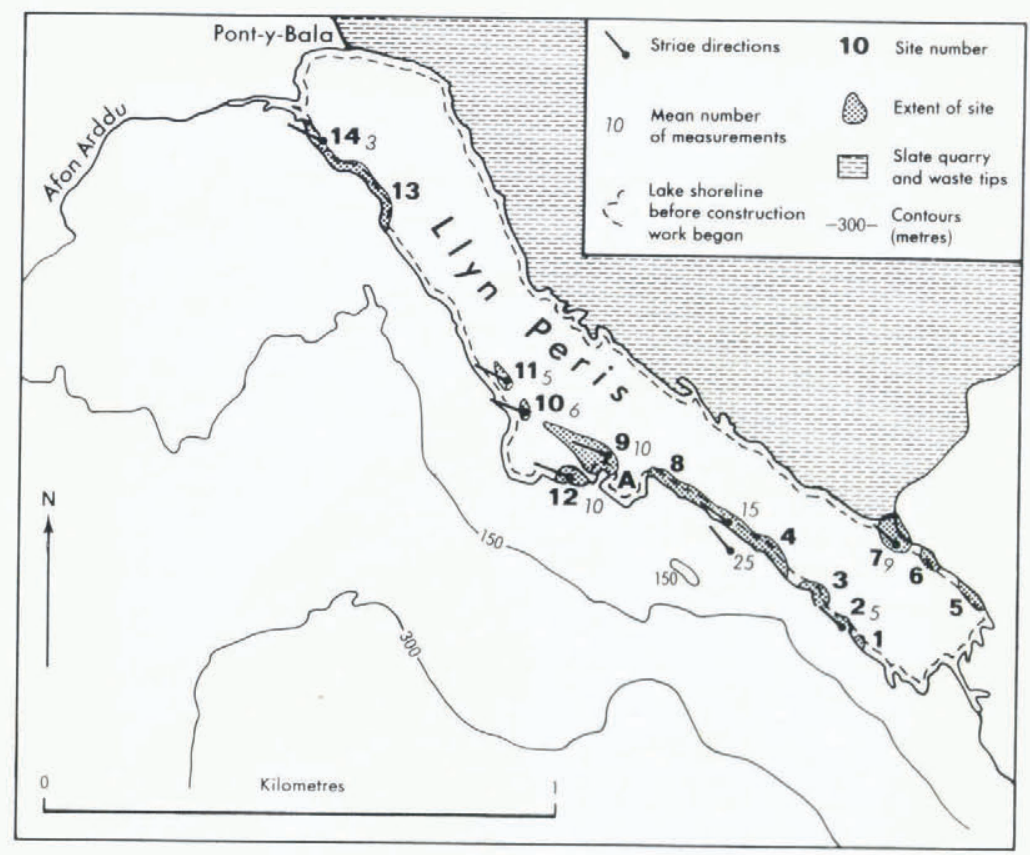

Fig. 2. Study sites and striae orientations at Llyn Peris.

contained several massive boulders, the largest of which measured about $8 \mathrm{~m}$ by $8 \mathrm{~m}$ by $5 \mathrm{~m}$. Even so, many of the bedrock surfaces described here had to be dug out or brushed clean of sediment.

The trough was last glaciated in the Late Devensian, probably becoming ice-free at least 13000 years ago (Coope and Brophy, 1972; Ince, unpublished). The basin was not glaciated during the Loch Lomond (Younger Dryas) stadial (Gray, 1982).

\section{Abrasion}

Abraded bedrock is the most striking feature of the bed of Llyn Peris. One of the main reasons is that the homogeneous fine-grained slate bedrock is particularly susceptible to scratching and polishing. Heavily abraded, steeply sloping slabs of slate up to $10 \mathrm{~m}$ high are found at sites 5, 6, 13, and 14 (Figs 2 and 3). It is noticeable that the striae on most of these faces indicate upward movement of the ice at $5-10^{\circ}$ in the direction of movement, though, where the ice moved against bedrock obstructions on the slopes, the striae can be seen to sweep upwards over the obstacles, sometimes reaching angles of inclination of over $20^{\circ}$ (e.g. at sites 13 and 14).

Striae orientations on flat surfaces have been measured at a number of sites and the means of 3-25 orientations taken at each site are plotted on Figure 2. The mean orientations at sites 9, 10, 11 , and 12 are $299^{\circ}, 299^{\circ}, 306^{\circ}$, and $299^{\circ}$, respectively, whereas those at sites 2,7 , and 4 are $318^{\circ}, 319^{\circ}$, and $325^{\circ}$, respectively, and indicate a slight change in direction of ice movement as it moved north-westward along the trough. Once past the confining steep slopes of the Pass of 


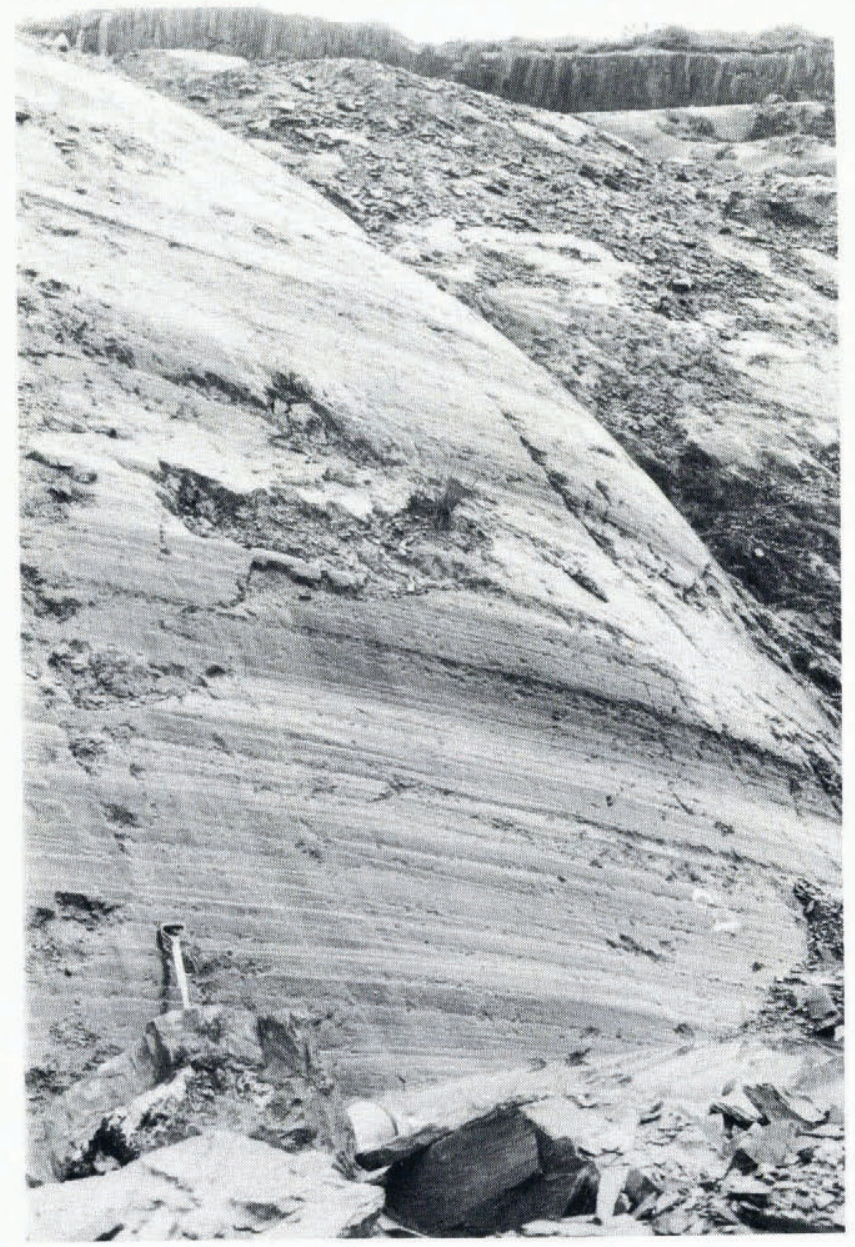

Fig. 3. Steep abraded face at site 6. Ice moved from right to left. Irregular blocks have been plucked from the face.

Llanberis at site 8 , the ice apparently swung into the bay on the south-west shore as it became less confined towards the wider valley stretch around Llanberis (see Fig. 2).

There are also many examples of small-scale topographic features influencing striae trends. For example, at site 7 , a dyke c. $1 \mathrm{~m}$ wide is responsible for a trench $1-1.5 \mathrm{~m}$ deep running transverse to the main trend of the striae, but the walls of the trench bear striae parallel to its trend. Leading down-ice from this transverse trench are several linear grooves about $0.5 \mathrm{~m}$ wide, all of which are joint-controlled. Striae can be seen to curve from the walls of the trench into the grooves, indicating streaming of the basal ice into them.

The best examples of striated glacial grooves occur in an embayment at site 9 . They are $10-30 \mathrm{~cm}$ wide and deep, rise steeply $\left(40-60^{\circ}\right)$ down-ice out of the embayment (see Fig. 4), and all follow joints. It is possible that these grooves owe their origin to "streaming" of debris-rich ice in this low point in the glacier bed in a way similar to that suggested by Boulton (1979). 


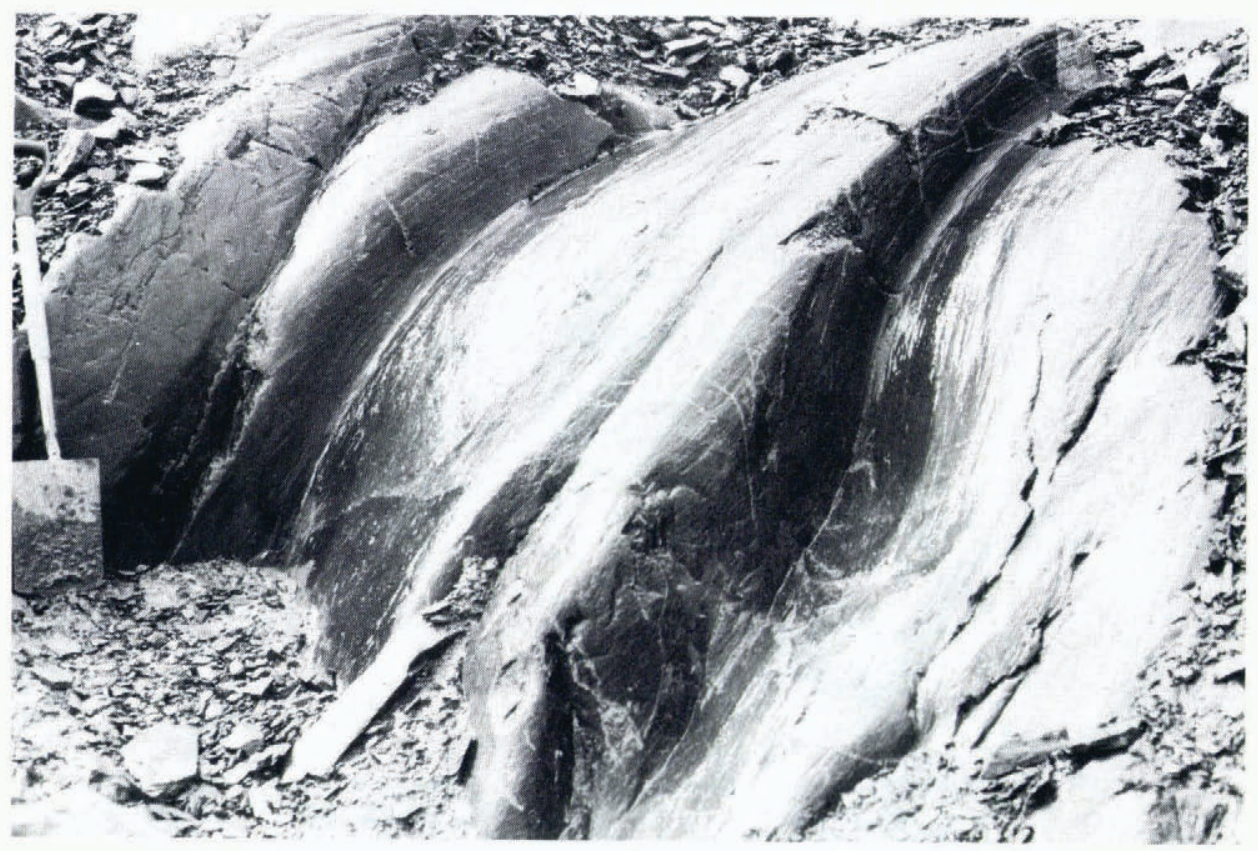

Fig. 4. Glacial grooves up which the ice moved at site 9.

Although such steeply rising deep grooves are confined to one part of site 9 , at several other localities there are shallow sinuous grooves into and out of which striae can be seen to converge and diverge. Horizontal grooves cut into steep faces also occur, the most impressive one at site 9 (Fig. 5). The floor of this groove exhibits the most highly polished slate in the study area.

Lithological differences have also had an effect on glacial abrasion. The strike of the original bedding in the metamorphosed mudstones and shales trends south-west to north-east and thus transverse to ice movement. At site 7, the smoothing towards the top of the curved stoss slope of an unjointed slate slab several metres square (Fig. 6) shows a marked change in angle and this is related to a change in lithology. The long lee slope at this site (7) is conspicuously stepped as a result of lithological changes and joints, but where homogeneous slate occurs on treads it is often remarkably well striated (see Fig. 6).

At site 13, two small more resistant patches occur within the slate, possibly as reduction spots or as offshoots from a dyke. Differential glacial abrasion has resulted in small-scale cragand-tail forms on the steep face (Fig. 7). Even smaller crag-and-tails are also present at this locality, emanating from numerous iron pyrites crystals a few millimetres square. These have often been weathered out, leaving square pits with slate tails extending down-ice for a few centimetres (Fig. 7).

\section{BEDROCK FRACTURE AND PLUCKING}

Although erosional processes have often been divided into abrasion and plucking, recently it has been recognized that fracture must occur before rock fragments can be plucked by ice. Thus, recent authors have discussed "bedrock fracture" or "crushing" separately from abrasion and 


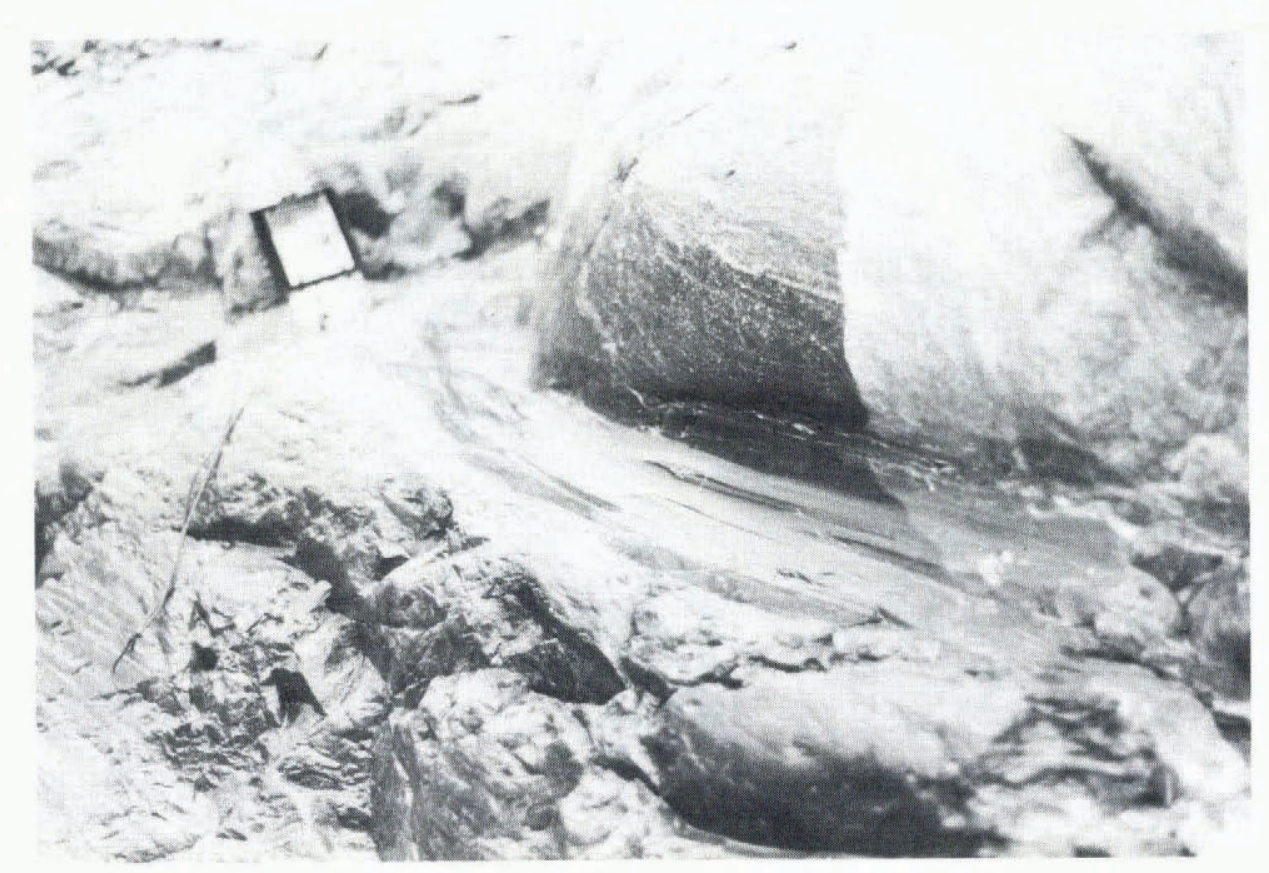

Fig. 5. Horizontal giacial groove at site 9. Ice moved towards the camera. The floor of the groove is very highly polished.

plucking (e.g. Boulton, [ $\left.{ }^{\mathrm{c}} 1974\right]$; Sugden and John, 1976). Boulton $\left(\left[{ }^{\mathrm{c}} 1974\right]\right)$ described three processes of bedrock fracture associated with glaciers, viz. freeze-thaw shattering, pressurerelease jointing, and lee-slope stress fracturing. To these processes can be added the production of friction cracks by clasts moving over bedrock (see e.g. Embleton and King, 1975), though some authors have classified this as abrasional (e.g. Johnson, unpublished).

Few examples of friction cracks have been found on the abraded bedrock in the Peris basin. Much more common are irregularly shaped transverse marks, where several chips of rock have been removed and which often extend several centimetres laterally beyond the confines of the striae and grooves to which they are related. Thus many surfaces have been given a roughened appearance perpendicular to ice movement (Fig. 8b) largely due to the exploitation of the transverse cleavage planes. In some cases (e.g. at site 14), regularity of form and spacing can be detected (see Figs $8 \mathrm{a}$ and 9) with curved chips concave up-ice having been removed from both sides of a groove, or, in some cases (e.g. upper one in Fig. 9), from one side only. The spacing of the chips varies from a few millimetres to less than $1 \mathrm{~mm}$. It remains to be seen whether they are unique to this area or to slate outcrops but, if not, the name "swallow-wing fractures" is proposed.

There are many localities where fracturing and plucking have been facilitated by the presence of jointing or cleavage in the slate. In some places, jointing is poorly developed leading to remarkably unbroken abraded areas of slate. In other places, however, abraded areas are broken by angular depressions of various size aligned along joints. Examples of removal of large plucked blocks occur at site 13, where a number of vertical joints break a steep face over $10 \mathrm{~m}$ high and 


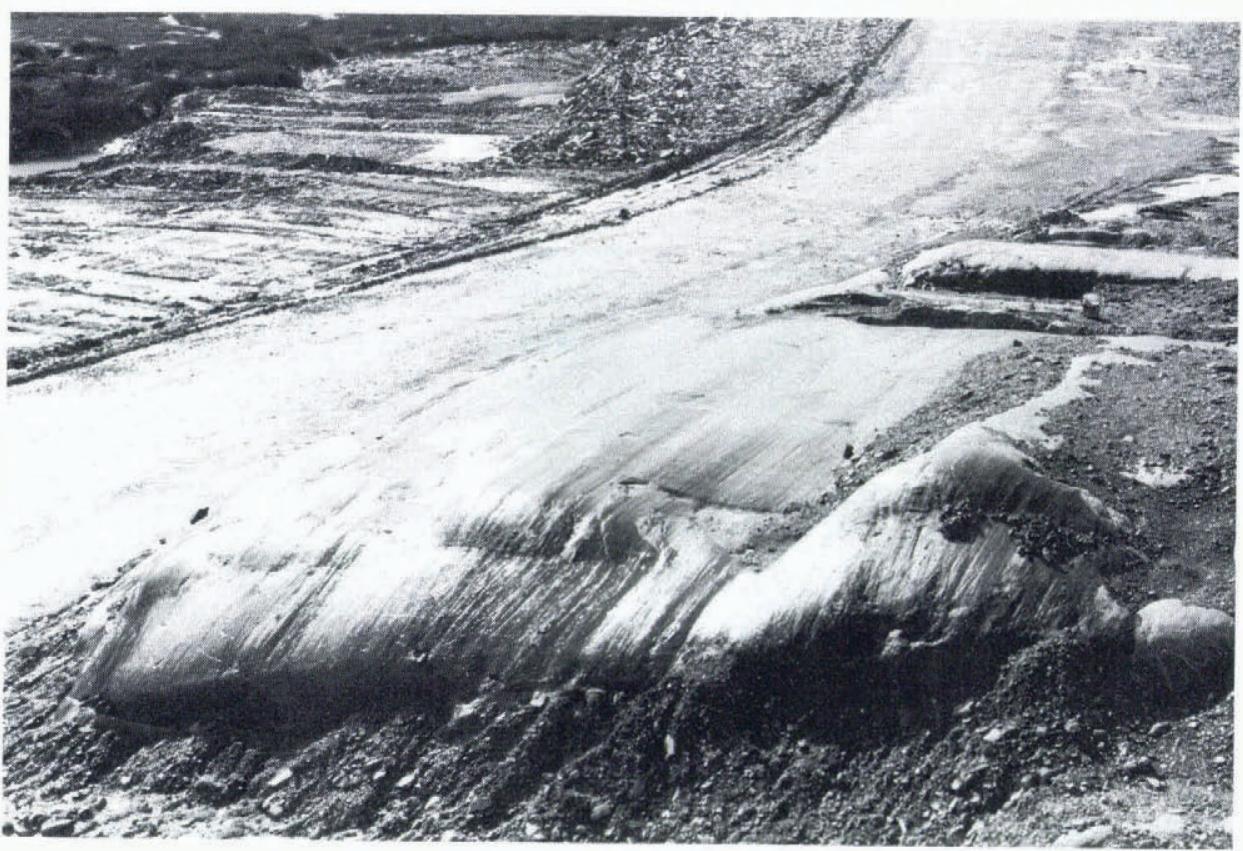

Fig. 6. Abraded pavement at site 7. The ice moved away from the camera. The stoss slope steepens at a change in lithology. Slate waste being used to cover the lake-floor sediments can be seen in the upper left corner.

$100 \mathrm{~m}$ long (Fig. 10). At site 7, the stepped appearance along the lee slope already described is partly due to transverse joints which led to the plucking of slate blocks, while at sites 9 and 12 the jointing trends north-south, somewhat oblique to the direction of ice movement, and a pronounced series of oblique trenches and ribs has resulted.

The role of cleavage in fracture and plucking is displayed at many of the same sites. As illustrated in Figure 11, the plucking of large blocks frequently results in flat abraded surfaces terminated abruptly by near-vertical, joint-controlled faces. On these faces, thin cleavagecontrolled sheets of slate have often been broken off to give an irregular appearance. This process results in a gradual retreat of the down-ice side of the abraded sections. It is probable that the same applies to joints on abraded faces. Initially, freezing of melt water may enlarge the joint but once widened other processes such as stress fracturing can act to further enlarge the basin by breaking off small fragments along cleavage planes. Support for this sequence comes from the observation that at Peris the joints are commonly enlarged in an up-ice direction. An example is shown in Figure 7.

\section{THE ROLE OF MELT WATER}

Although plucking has resulted in many lee slopes that conform to the classic angular form, it was noticeable that at Peris many sharp edges had been rounded off. Indeed, smoothed lee faces with small shallow bowls are very common in the study area (e.g. at sites 2, 3, 4, 5, 9, and 


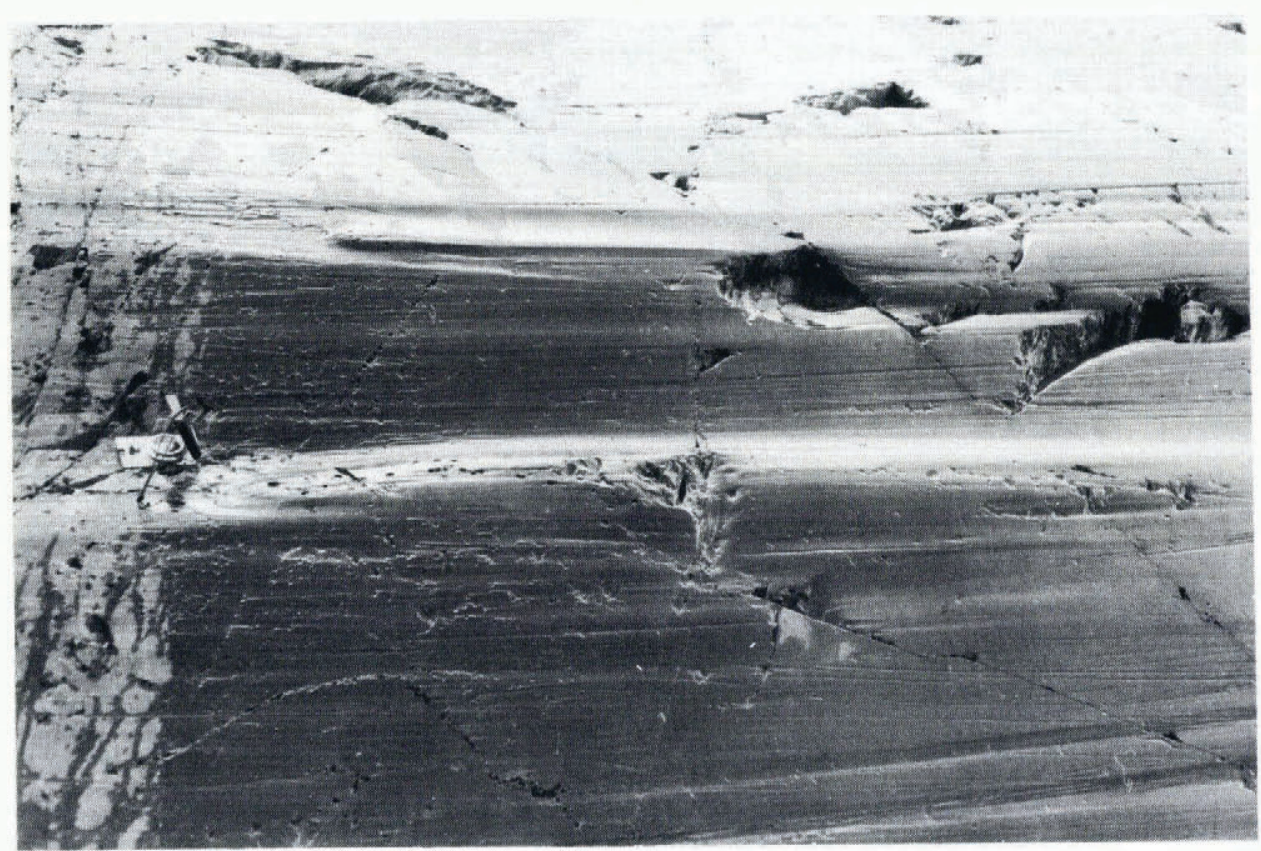

Fig. 7. Small-scale crag-and-tails developed at two resistant patches in the slate at site 13. Ice moved left to right. On the left, iron pyrites crystals have formed miniature crag-and-tails though the crystals themselves have mostly been weathered out leaving slate tails in the lee of rusty square pits. In the right centre, a joint has been preferentially widened up-ice.

a

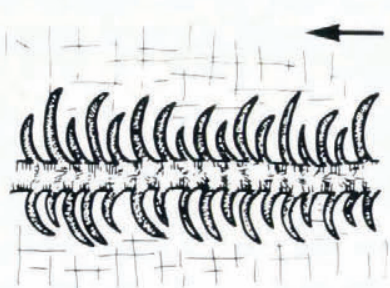

b

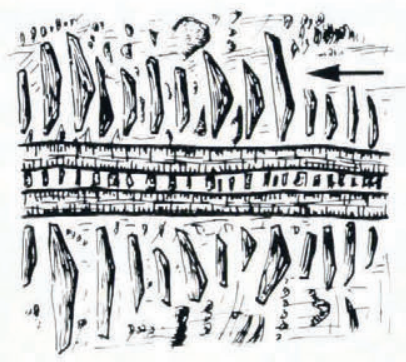

C

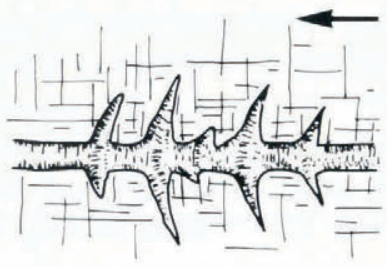

d

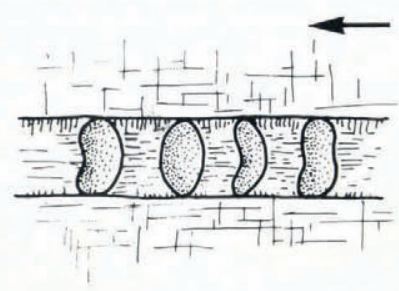

Fig. 8. Transverse friction marks associated with striae and abrasion grooves. a. New type from Llyn Peris; b. Irregular transverse chipping common at Llyn Peris; c. Crescentic gouges related to a groove ("jagged groove" of Harris (1943)); d. Chattermarks in a groove (from Harris, 1943). 


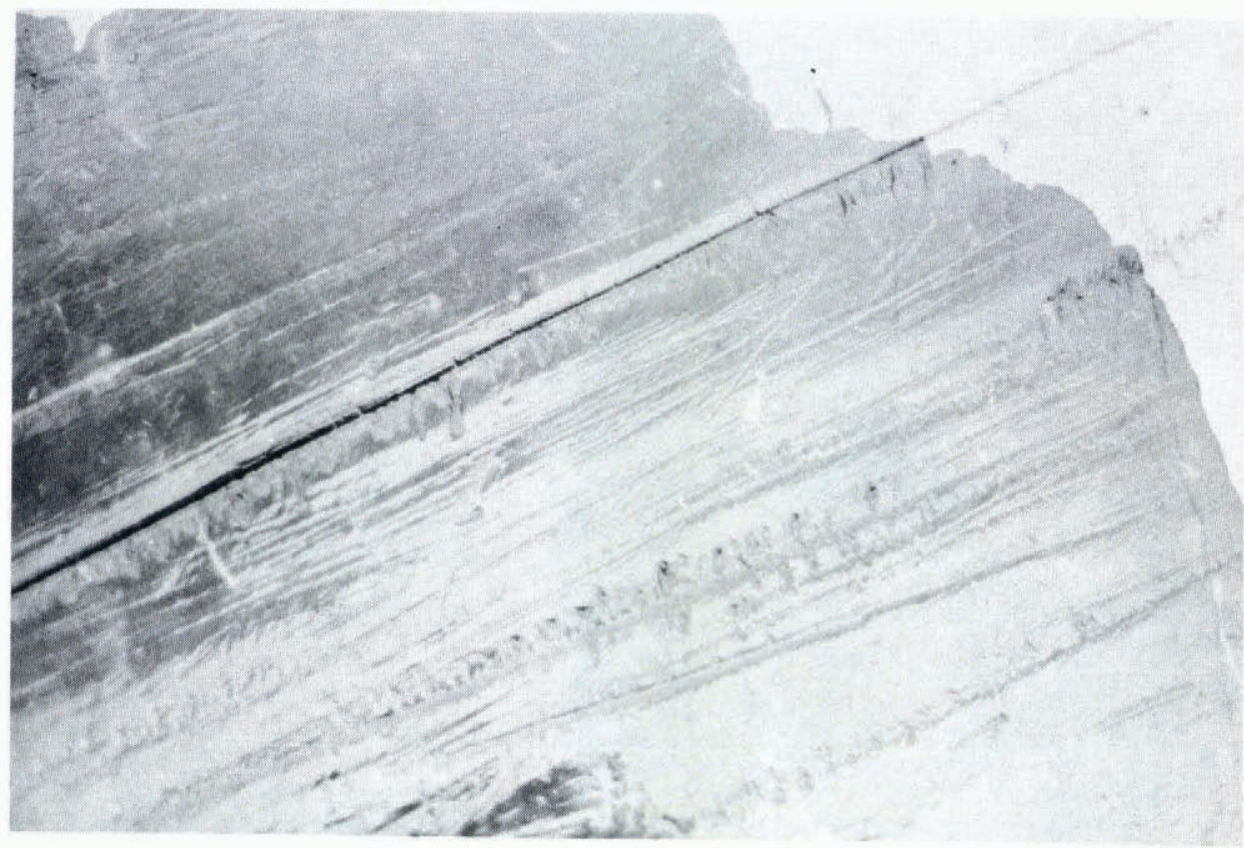

Fig. 9. Transverse friction cracks at site 14. Ice moved from left to right.

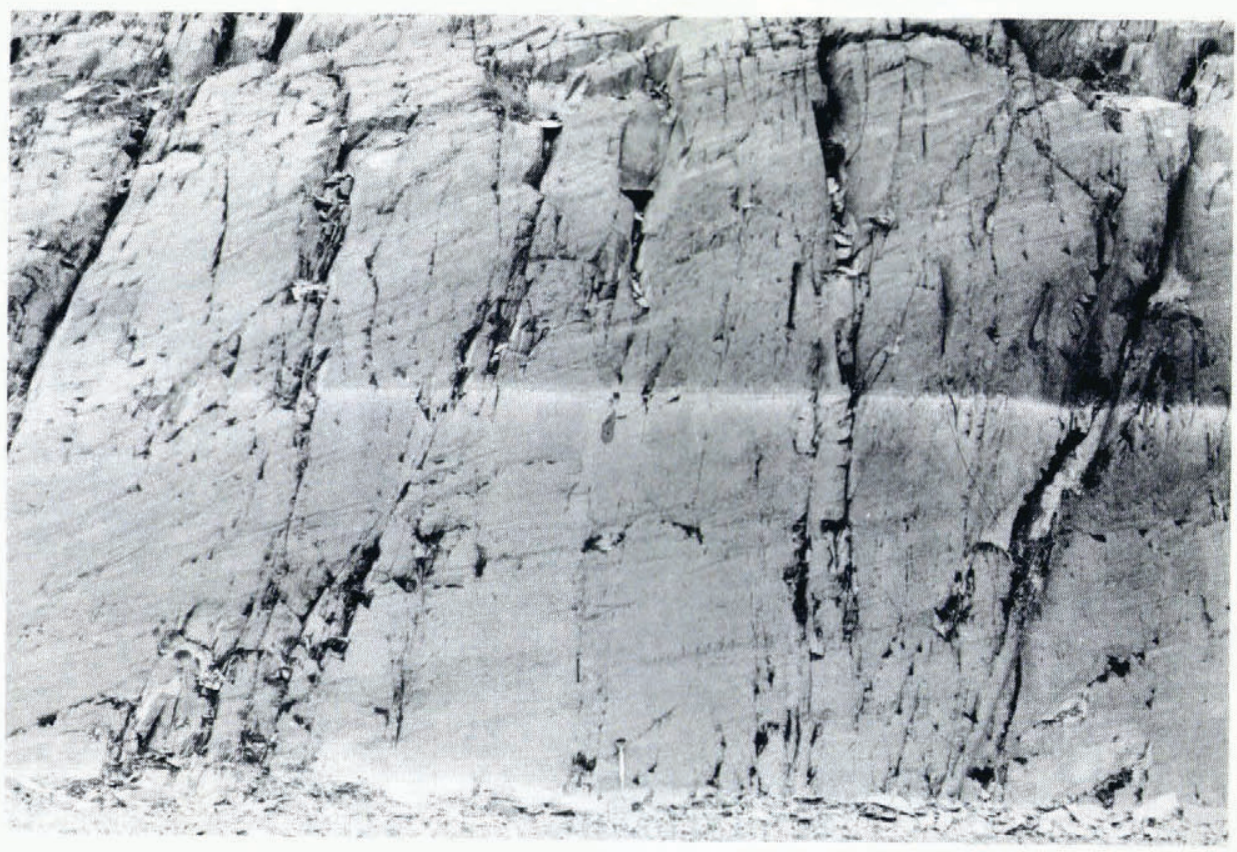

Fig. 10. Plucking associated with vertical joints at site 13. Ice moved from left to right and striae are rising at $5-10^{\circ}$. 


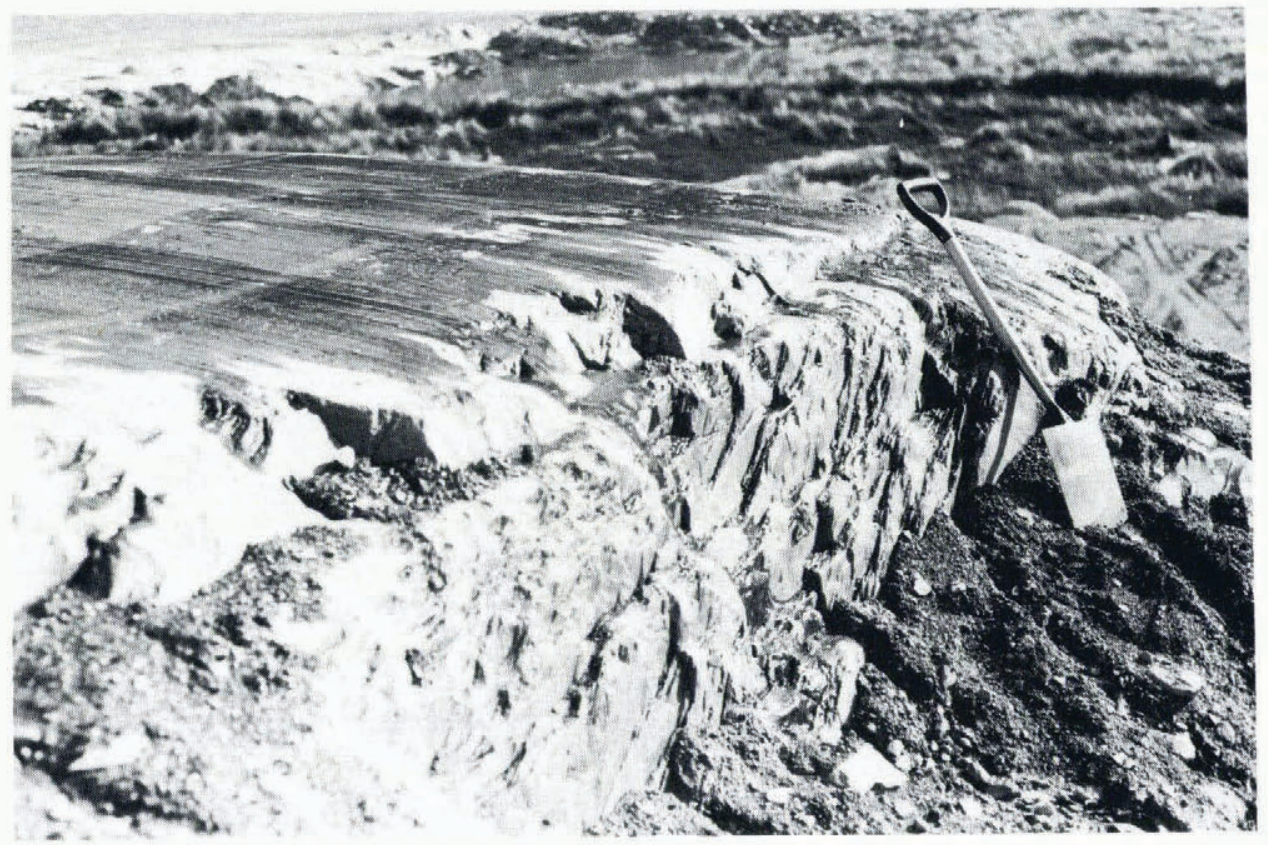

Fig. 11. Plucking associated with slate cleavage on the lee side of the abraded pavement shown in Figure 6.

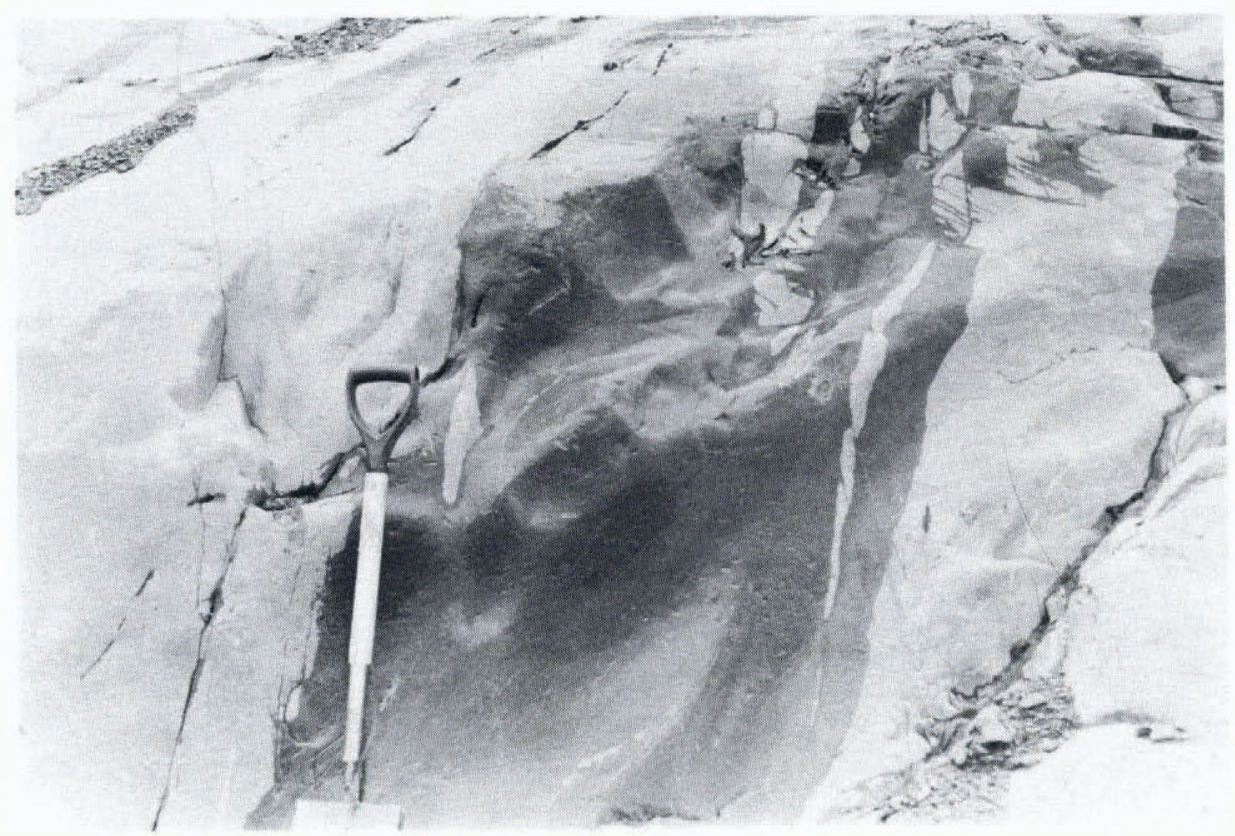

Fig. 12. Smoothed and rounded slope in the lee of an abraded outcrop. Ice moved left to right. 


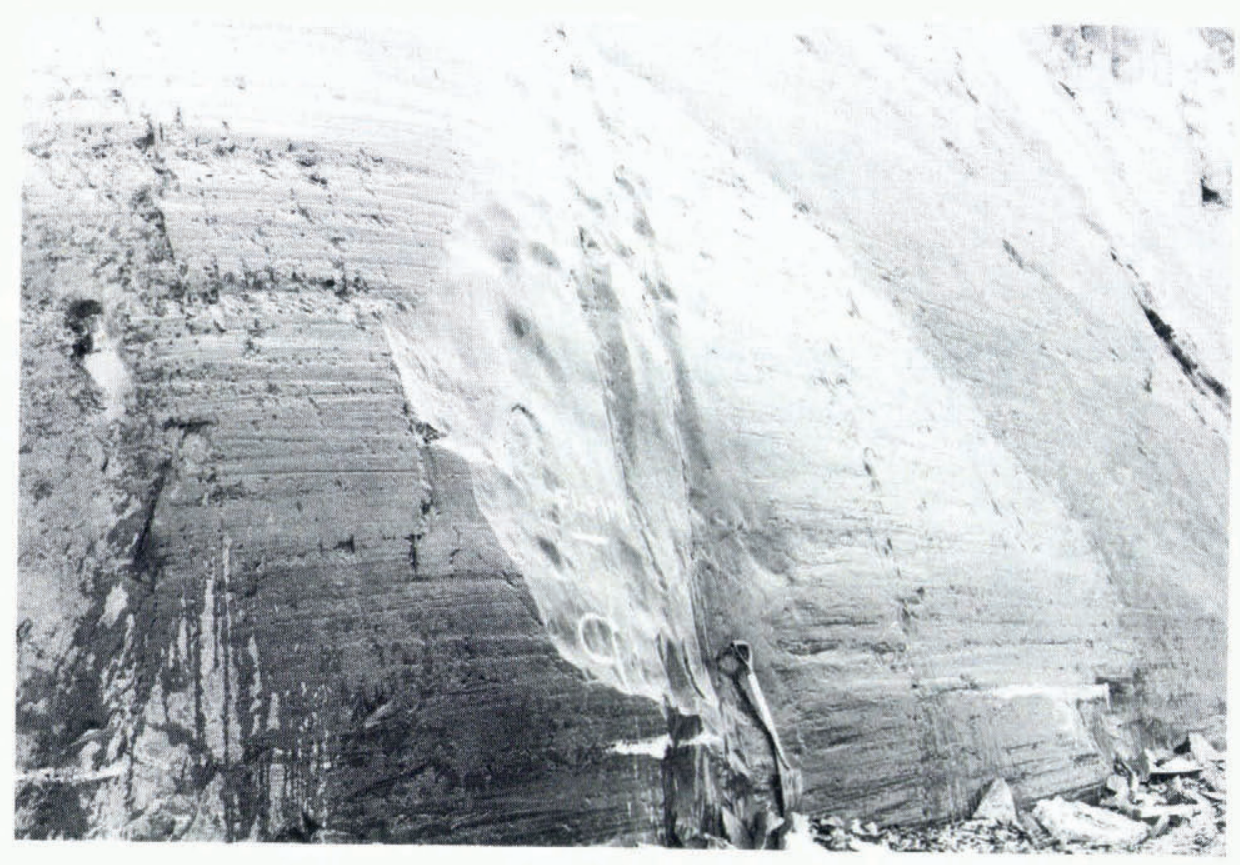

Fig. 13. Smoothed bedrock separating abraded sections at site 13. Ice moved left to right.

13) and an example is shown in Figure 12. Since the features resemble melt-water-produced forms observed by Vivian and Bocquet (1973) in cavities below the glacier d'Argentière in the French Alps, it is suggested that this is the most likely explanation for the widespread smoothing of lee slopes at Peris.

Another example is shown in Figure 13. On the left and right of the photograph the steep faces are heavily abraded but they are separated by a patch of bedrock which in general is smooth, unstriated, and scalloped in places. Although the area concerned is 3-4 m high and up to $2 \mathrm{~m}$ wide, it is only a few centimetres deep relative to the abraded surfaces on either side. The implication is that a very shallow subglacial cavity existed at this point, and its failure to close must indicate rapidly moving ice. There is clear evidence that abrasion and melt water were occurring contemporaneously, for on the bedrock area on the right of Figure 13 there are places where melt-water erosion has failed to erode the deeper sections of an abraded face, yet the smooth melt-water-eroded face is itself abraded.

There are a few other features for which melt-water erosion is a possible origin. At site 8 a number of curves and facets, sometimes with sharp edges and with striated grooves extending down-ice, occur on a vertical rock face (Fig. 14). They resemble some sichelwannen in a similar situation illustrated by Sugden and John (1976, fig. 15.1).

Figure 15 illustrates another example of a feature whose origin is in some doubt. It is a sinuous channel about $1 \mathrm{~m}$ wide with sharp edges in part, a striated floor, and overdeepened sections. It is one of a group of similar forms occurring at site 7 , down-ice from the crest of a rock obstruction. In many ways it resembles several of the p-forms recently studied by the present author on the Isle of Mull, Scotland, though unlike the vast majority of the Mull features 


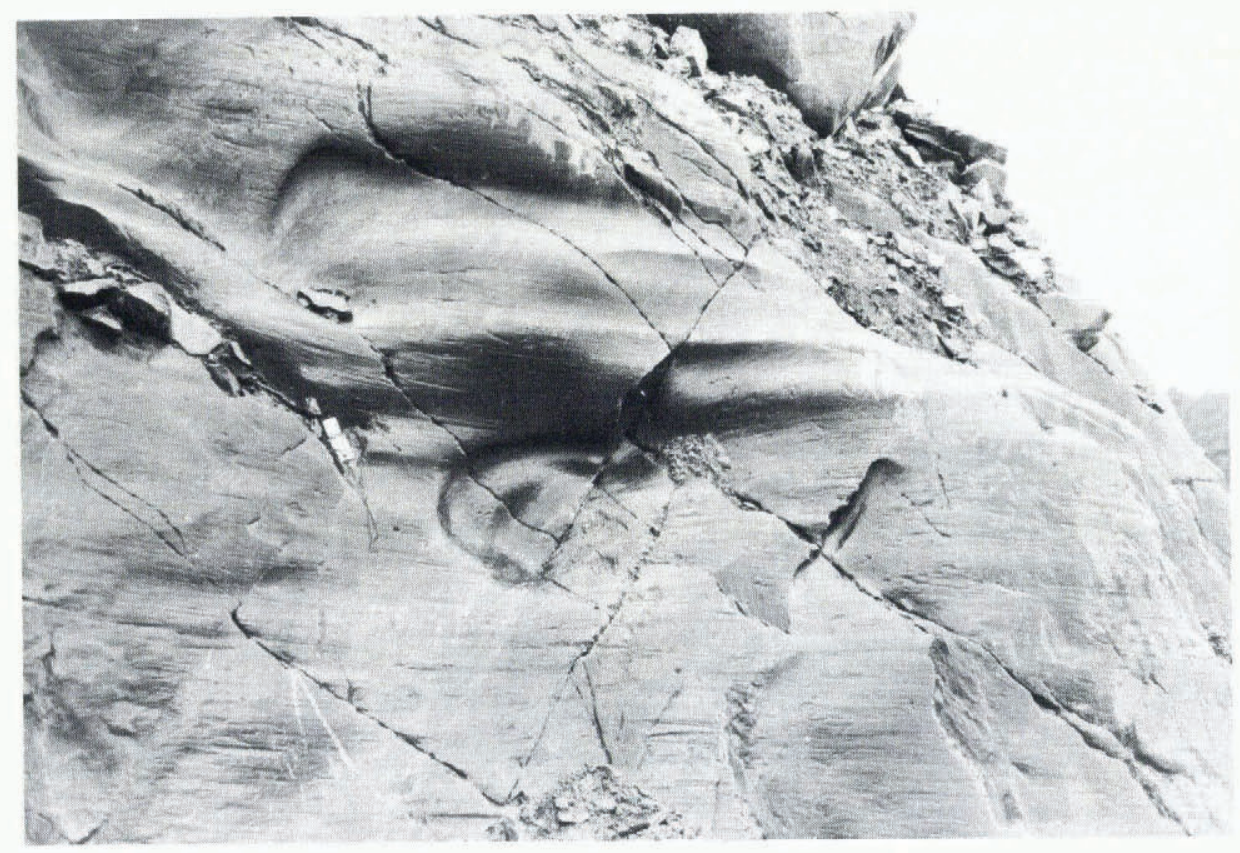

Fig. 14. Possible sichelwannen at site 8. Ice moved from left to right. Note the striae and also how the features largely disregarded the joints.

(and those in Figure 14), it is developed along a joint. The Mull p-forms were explained by meltwater corrasion and/or cavitation, with active ice subsequently moving through the channels to striate them (Gray, 1981). This origin is favoured for the Llyn Peris features shown in Figures 14 and 15. Alternative processes are till squeezing (Gjessing, 1965) or glacial abrasion (Boulton, $\left.\left[{ }^{c} 1974\right]\right)$. The latter has been invoked in this paper to explain large grooves but the features in Figures 14 and 15 differ in having flat beds and only superficial striations. It is likely, therefore, that "grooves" or "channels" can be created in various ways and that some have complex origins.

\section{DISCUSSIONS AND CONCLUSIONS}

\section{Processes}

In many standard texts, erosion of bedrock during glaciation is described as being due to two processes, abrasion and plucking, but it is now clear that the processes involved are far more complex. First, we must add the processes of bedrock fracture and melt-water erosion, and allow for the possibility of erosion by squeezing of subglacial till. Secondly, it must be realized that each of these categories involves several processes. Abrasion involves at least two processes, viz. scratching (by coarse debris) and polishing (by fine particles). Bedrock fracture occurs in at least four ways, viz. freezing of melt water in lines of weakness, pressure-release jointing, stress fractures on lee slopes, and abrasion cracking. Plucking or entrainment can arise in at least four ways, viz. freezing of debris on to glacier soles by regelation, freezing of glacier soles to already 


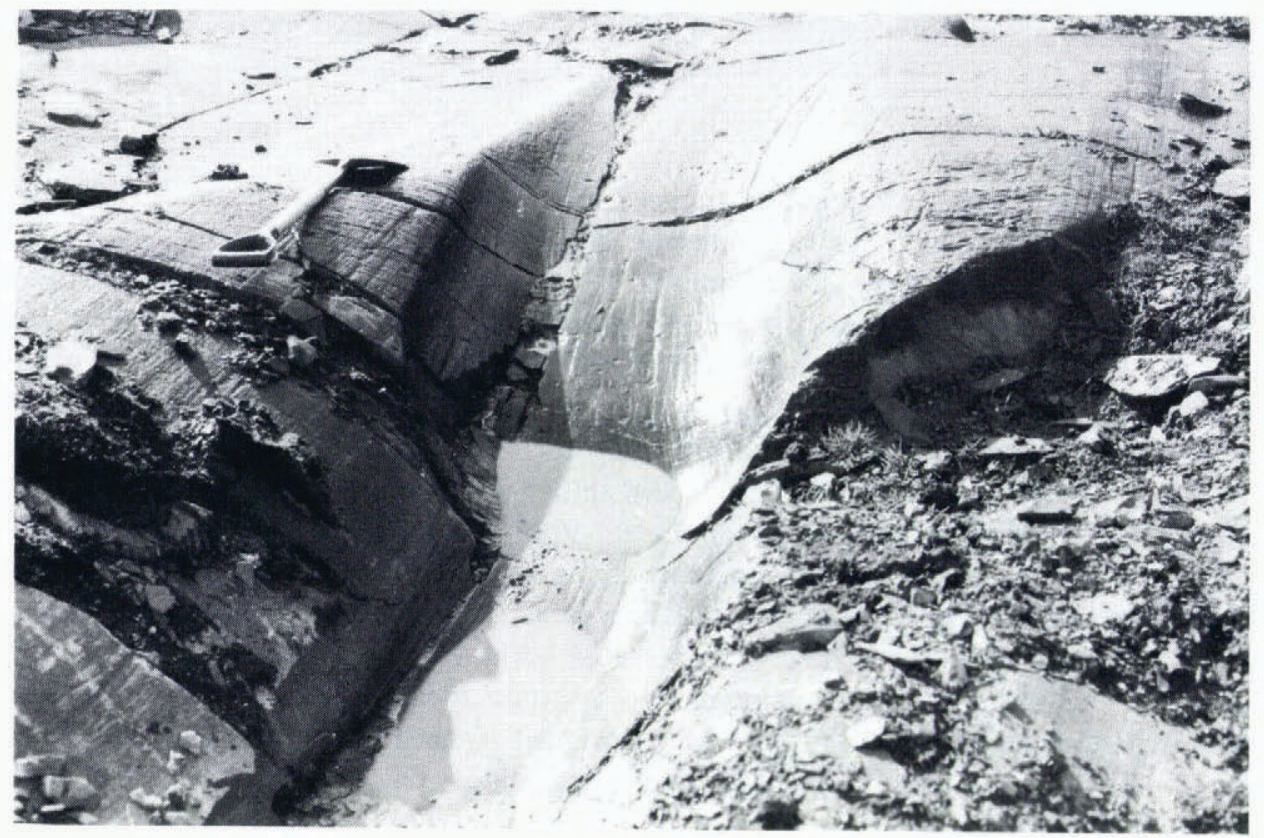

Fig. 15. Striated channel at site 7 with overdeepened floor, longitudinal joint, and sharp edge on the left. Ice moved away from the camera.

loosened blocks and subsequent movement, heave of debris into the glacier base, and encasement by glacier flow round large blocks. Finally, melt water may erode by cavitation or corrasion.

This study has found much evidence to support the importance of melt-water erosion on lee slopes. Rather than being angular and fractured, as in the traditional descriptions of the lee slopes of roches moutonnées, lee slopes at Llyn Peris are often smoothed and scalloped or have the sharp edges rounded off.

As regards bedrock fracture, this study indicates that in areas of highly cleaved rocks, transverse fracturing is an under-emphasized process and at Peris has commonly resulted in irregular forms. The most detailed study of transverse friction cracks is by Johnson (unpublished), mainly based on a theoretical treatment of contact-induced stress fractures. An important parameter used by Johnson was the $T / N$ ratio, where $T$ is the contact shear force and $N$ the contact normal force. Along the side slopes of a glacier trough such as at Peris, the shear force will be very high relative to the normal force and the result is a predominance of striae and lack of friction cracks. The ratio can, however, be affected by the topography and it is noticeable that at Peris transverse erosional forms are most common on slopes that are angled up-ice (e.g. at sites 4 and 14).

As Figure 8a shows, "swallow-tail fractures" have a different form from crescentic gouge trails (Fig. 8c) described by Harris (1943) as "jagged grooves". They may, however, be related to very similar stress conditions as illustrated by the $S 2$ stress trajectories calculated by Johnson (unpublished, fig. 3.27). However, Johnson's argument that crescentic gouges are formed by rolling rather than sliding blocks is difficult to reconcile with their close association, in the case of jagged grooves, with regular striae or grooves suggesting sliding blocks. As Johnson pointed out, 
friction cracks have the potential for teaching us much about the motion of basal ice as it moves over an undulating bed, but we are still far from understanding their formation.

\section{Direction of ice movement}

Much has been written on the use of transverse friction cracks in determining directions of ice movement. It is now clear that the occurrence of both crescentic and reversed gouges, as well as oblique examples, poses some constraints on the use of this morphological type (Andersen and Sollid, 1971; Gray and Lowe, 1982). Similarly, lunate fractures are unlikely to be of widespread use, since only a very few examples have ever been described in the 40 years since first observed by Harris (1943). It is worth noting that he himself only described two examples. The smaller-scale forms are likely to be of greater use. Many hundreds of crescentic fractures have been identified and all but a few have been shown to be concave down-ice (Lahee, 1912; Dreimanis, 1953; Thorp, 1981; Gray and Lowe, 1982; Johnson, unpublished). Similarly, all jagged grooves so far described have gouges concave up-ice. The "swallow-wing" fractures identified in this study are similarly related and may be useful if found elsewhere.

This study has also identified the potential of using small-scale crag-and-tails in reconstructing directions of ice movement. In this study the "crags" are reduction spots or offshoots from a dyke with miniature examples formed by iron pyrites crystals, but there are likely to be other types of "crag" associated with other bedrock lithologies.

\section{Research potential}

The Llyn Peris features are remarkably fresh despite the fact that it is at least 13000 years since they were formed. It is suggested that Man's increasing technological skills will present glacial geomorphologists with similar research and teaching opportunities in the future and these will be particularly valuable in countries like Britain which have no present-day glaciers. It is worth noting that important discoveries were made recently at a pumped storage site at Lough Nahanagan in Ireland, where radiocarbon dating of organic muds incorporated in delicate end moraines on the lake bed allowed the glacier advance to be dated to the Younger Dryas (Colhoun and Synge, 1980).

\section{ACKNOWLEDGEMENTS}

I am very grateful to the Central Research Fund Committee of the University of London for a grant towards the cost of field work, and to Dr A. Rogers of the Central Electricity Generating Board at Llanberis for arranging access to the lake bed during construction work, and for supplying bore-hole data. Mr T. J. Lawson, Dr J. J. Lowe, Mr J. Rose, Dr J. B. Sissons, and Dr D. G. Sutherland provided valuable comments on an early draft of this paper.

MS. received 13 July 1981

\section{REFERENCES}

Andersen, J. L., and Sollid, J. L. 1971. Glacial chronology and glacial geomorphology in the marginal zones of the glaciers Midtdalsbreen and Nigardsbreen, south Norway. Norsk Geografisk Tidsskrift, Bd. 25, Ht. 1, p. 1-38. 
Boulton, G. S. ['1974.| Processes and patterns of glacial erosion. (In Coates, D. R., ed. Glacial geomorphology. Binghamton, N.Y.. State University of New York, p. 41-87. (Publications in Geomorphology.))

Boulton, G. S. 1979. Processes of glacier erosion on different substrata. Journal of Glaciology, Vol. 23, No. 89, p. 15-38.

Colhoun. E. A., and Synge, F. M. 1980. The cirque moraines at Lough Nahanagan, County Wicklow, Ireland. Proceedings of the Royal Irish Academy, Vol. 80B, No. 2, p. 25-45.

Coope, G. R., and Brophy, J. A. 1972. Late Glacial environmental changes indicated by a coleopteran succession from North Wales. Boreas, Vol. 1, No. 2, p. 97-142.

Dreimanis, A. 1953. Studies of friction cracks along the shores of Cirrus Lake and Kasakokwog Lake, Ontario. American Journal of Science, Vol. 251, No. 11, p. 769-83.

Embleton, C., and King, C. A. M. 1975. Glacial geomorphology. [Glacial and periglacial geomorphology. Second edition. Vol. l.] London, Edward Arnold.

Gjessing, J. 1965. On "plastic scouring" and "subglacial erosion". Norsk Geografisk Tidsskrift, Bd. 20, Ht. 1-2, p. 1-37.

Gray, J. M. 1981. p-forms from the Isle of Mull. Scottish Journal of Geology, Vol. 17, No. 1, p. 39-47.

Gray, J. M. 1982. The last glaciers (Loch Lomond Advance) in Snowdonia, North Wales. Geological Journal, Vol. 17, No. 2, p. 111-33.

Gray, J. M., and Lowe, J. J. 1982. Problems in the interpretation of small-scale erosional forms on glaciated bedrock surfaces: examples from Snowdonia, North Wales. Proceedings of the Geologists' Association, Vol. 93, No. 4. p. $403-14$.

Harris, S. E. 1943. Friction cracks and the direction of glacial movement. Journal of Geology, Vol. 51, No. 4 , p. 244-58.

Ince, J. Unpublished. Pollen analysis and radiocarbon dating of Late-glacial and early Flandrian sediments in Snowdonia, North Wales. [Ph.D. thesis, City of London Polytechnic, 1981.]

Johnson, C. B. Unpublished. Characteristics and mechanics of formation of glacial arcuate abrasion cracks. |Ph.D. thesis, Pennsylvania State University, 1975.]

Lahee, F. H. 1912. Crescentic fractures of glacial origin. American Journal of Science, Vol. 33, No. 193, p. $41-44$.

Sugden, D. E., and John, B. S. 1976. Glaciers and landscape: a geomorphological approach. London, Edward Arnold.

Thorp, P. W. 1981. An analysis of the spatial variability of glacial striae and friction cracks in part of the western Grampians of Scotland. Quaternary Studies (City of London Polytechnic and Polytechnic of North London), Vol. 1, p. 71-94.

Tinsley, H. M., and Derbyshire, E. 1976. Late-glacial and postglacial sedimentation in the Peris-Padarn rock basin, North Wales. Nature, Vol. 260, No. 5548, p. 234-38.

Vivian, R. A., and Bocquet, G. 1973. Subglacial cavitation phenomena under the glacier d'Argentiere, Mont Blanc, France. Journal of Glaciology, Vol. 12, No. 66, p. 439-51. 